\title{
Heilsukvíði - aukin pekking og meðferðarmöguleikar
}

Sóley Dröfn Davíosdóttir ${ }^{1}$ klínískur sálfræðingur

Ólafur Árni Sveinsson ${ }^{2}$ taugalæknir

Lykilorð: heilsukvíði, líkömnunarraskanir, hugræn atferlismeðferð, serótónínendurupptökuhemlar.

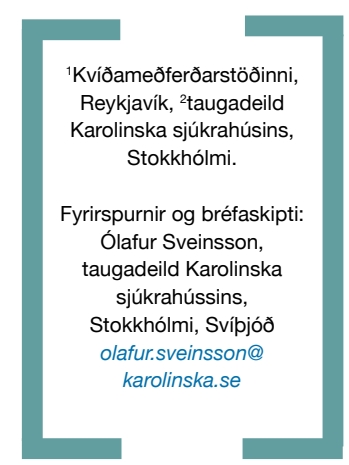

\section{Ágrip}

Heilsukvíði einkennist af óhóflegum og hamlandi kvíða par sem fólk óttast að vera haldið alvarlegum sjúkdómi prátt fyrir að niðurstöður læknisskoðana og rannsókna bendi til annars. Heilsukvíðnir hafa margir hverjir ítrekað gengist undir læknisrannsóknir sem ekki hafa verið til pess fallnar að veita trúverðugar skýringar á peim vanda sem fyrir er. Endurteknar fregnir af pví hvað sé líklegast ekki að hrjá hinn heilsukvíðna slær aðeins á kvíða hans í skamman tíma og getur aukið á ráðaleysið og grafið undan trausti hans á heilbrigðiskerfið pegar til lengri tíma er litið.

Aukinn áhugi hefur vaknað á heilsukvíða á síðastliðnum árum og áratugum. Ekki síst er pað góður árangur hugrænnar atferlismeðferðar sem getið hefur af sér pennan aukna áhuga. Samkvæmt hugrænu skýringarlíkani á heilsukvíði rætur í og er viðhaldið af rangtúlkunum á eðlilegum líkamseinkennum. Auk pess hefur lyfjameðferð með sértækum serótónín-endurupptökuhemlum getið af sér ágætis árangur. Hefur vandinn löngum pótt illviðráðanlegur en með hugrænni atferlismeðferð og/eða lyfjameðferð hefur náðst betri árangur í meðferð pessa oft illvíga vanda. Tilgangur pessarar greinar er að auka pekkingu íslensks heilbrigðisstarfsfólks á heilsukvíða og ekki síst að gera grein fyrir auknum meðferðarmöguleikum.

\section{Inngangur}

Hóflegar áhyggjur af heilsunni geta verið gagnlegar og stuðlað að heilsusamlegu líferni. Hjá sumum verða pessar áhyggjur hins vegar að óhóflegum og hamlandi kvíða par sem fólk óttast að vera haldið alvarlegum sjúkdómi prátt fyrir að niðurstöður læknisskoðana og rannsókna bendi til annars. Petta ástand nefnist á ensku hypochondriasis og var áður pýtt sem ímyndunarveiki. Ekki er sú pýðing heppileg pví vanlíðanin sem vandanum fylgir er engin ímyndun. Undanfarið hefur orðið heilsukvíði (health anxiety) verið notað og mun pað einnig gert hér. Greiningarskilmerki heilsukvíða (DSM-IV) má sjá í töflu I. ${ }^{1}$

Heilsukvíði er flokkaður með líkömnunar- röskunum í bæði DSM-IV og ICD-10 greiningarkerfunum. Einkennast pessar raskanir af líkamlegum einkennum sem talin eru eiga sér sálrænar orsakir. Undir pennan flokk heyra geðraskanir, svo sem hugbrigðaröskun (conversion disorder) og líkamsgervingarheilkenni (somatisation disorder).

Heilsukvíðnir hafa ósjaldan gengið á milli lækna og eiga margir hverjir flókna sjúkrasögu að baki. Prátt fyrir ítarlegar rannsóknir eru peir oft óánægðir með pjónustuna sem peir hafa fengið enda hafa peir oftar fengið að heyra hvað sé $e k k i$ að peim en trúverðugar skýringar lækna á pví hvað sé raunverulega að hrjá pá. ${ }^{2}$ Peir upplifa að peim sé illa sinnt og ekki teknir alvarlega. Pví missa peir oft traust á læknum og telja pá illfæra um réttar sjúkdómsgreiningar. Á sama hátt geta pessir einstaklingar reynst læknum erfiðir. Læknarnir upplifa að heilsukvíðnir hlusti ekki á pá, treysti peim ekki og leiti til annarra lækna og erfiðlega gengur að sannfæra pá um að vandinn eigi sér sálrænar rætur. ${ }^{3}$

Aukinn áhugi hefur vaknað á heilsukvíða á síðastliðnum árum og áratugum. Ekki síst er pað góður árangur hugrænnar atferlismeðferðar sem

Tafla I. Greiningarskilmerki heilsukvíða. ${ }^{1}$

Viðkomandi er gagntekinn af peirri hugmynd að hann sé haldinn alvarlegum sjúkdómi sökum mistúlkunar á líkamlegum ópægindum eða breytingum.

Pessi hugmynd viðhelst prátt fyrir viðeigandi læknisfræðilegt mat og hughreystingar.

Hugmyndin um að vera haldinn alvarlegum sjúkdómi er ekki ranghugmynd í ströngum skilningi eins og í hugvilluröskun (delusional disorder) og takmarkast ekki við áhyggjur af útlitinu eins og líkamslýtaröskun (body dysmophic disorder).

Röskunin hefur í för með sér markverða pjáningu eða minnkaða starfshæfni.

Ástandið hefur varað í að minnsta kosti sex mánuði.

Vandinn skýrist ekki betur af almennri kvíðaröskun, práhyggju- og árátturöskun, felmtursröskun, punglyndisskeiði, aðskilnaðarkvíða eða annarri líkömnunarröskun. 
getið hefur af sér pennan aukna áhuga. Víða, meðal annars á Norðurlöndunum, hafa verið stofnsettar sérstakar göngudeildir par sem fengist er fyrst og fremst við pennan vanda. En áður en heilsukvíði er ræddur sérstaklega verður tekið dæmi af manni sem haldinn er pessum vanda.

\section{Tilfelli}

Gunnar er 41 árs gamall og hefur lengi glímt við mikinn heilsukvíða, en móðir hans lést pegar hann var 14 ára gamall af völdum krabbameins sem uppgötvað var á lokastigi. Gunnar hefur farið 1 gegnum mörg tímabil par sem hann hefur talið sig vera haldinn alvarlegum sjúkdómum. Í fyrra taldi hann sig vera með eitlakrabbamein sem leiddi loks til sýnatöku. Fyrir fjórum árum taldi hann sig vera með heilaæxli vegna spennuhöfuðverkjar sem endaði með segulómskoðun. Í dag getur hann minnst pessara uppákoma með bros á vör en pað kemur ekki í veg fyrir að hann óttist nú að vera haldinn MS (heila- og mænusiggi). Undanfarna mánuði hefur hann fundið fyrir dofa af og til á nokkrum stöðum vinstra megin í líkamanum. Fyrir um hálfu ári fann hann fyrir svima í eina viku, sem gekk yfir af sjálfu sér. Gunnar hefur lesið sér mikið til um MS og finnst lesturinn renna stoðum undir grunsemdir hans. Hann telur sig uppfylla skilmerki sjúkdómsins, taugaeinkenni sem samrýmast MS (dofa og svima) frá tveimur aðskildum hlutum taugakerfisins á mismunandi tímum.

Gunnar fór til heimilislæknisins sem taldi afar ólíklegt að hann væri haldinn sjúkdóminum en sendi engu að síður beiðni til taugalæknis að ósk Gunnars, og fékk par tíma eftir prjá mánuði. Í millitíðinni leitaði Gunnar, viðpolslaus af áhyggjum, til bráđamóttökunnar, og bað um steragjöf sem hann hafði lesið sér til um að gæfist vel við MS-köstum.

Við skoðun par fundust engin teikn um taugasjúkdóm. Pó að læknirinn teldi ekki pörf á frekari rannsóknum náði Gunnar í sömu viku að knýja fram segulómun af höfði og mænu, auk mænuvökvaprófs. Reyndust rannsóknirnar eðlilegar nema að prír ósértækir flekkir sáust íhvíta efninu umhverfis heilahólfin. Sjúkrahúslæknirinn útskýrði fyrir Gunnari að engin teikn væru um MS en að prír ósértækir flekkir sæjust á segulómskoðun af höfði. Fyrir Gunnari var petta staðfesting á pví að hann væri haldinn MS. Hann spurði lækninn hvort hann gæti útilokað að petta væru breytingar af völdum MS. Læknirinn sagðist nokkuð viss í sinni sök og útskýrði að margir væru með slíkar breytingar án pess að um sjúkdóm væri að ræða. Pessar skýringar nægðu Gunnari ekki, hann taldi að einkennin hlytu að eiga sér vefræna orsök.

Á pessum tímapunkti var kvíðinn orðinn svo mikill að Gunnar var hættur að geta sinnt starfi sínu, átti erfitt með svefn og pað hrikti í stoðum hjónabandsins. Óvissan var honum svo erfið að hann var farinn að óska pess að fá einhverja sjúkdómsgreiningu í stað pess að fá ítrekað pau skilaboð að „ekkert væri að“. Gunnar fékk meðhöndlun með serótónín endurupptökuhemli í stigvaxandi skömmtum og var vísað til sálfræðings sem hann pó var tregur til að hitta í fyrstu. Hann sá ekki tengslin milli líkamlegu einkennanna og pess að taka geðlyf, hvað pá að hitta sálfræðing. Hann viðurkenndi pó að kvíðinn, svefnerfiðleikarnir og áhyggjurnar væru honum um megn. Eftir nokkrar vikur af lyfja- og sálfræðimeðferð minnkaði kvíðinn til muna og hjálpaði sálfræðimeðferðin Gunnari að öðlast innsýn í pann hugarfarslega vítahring sem hann var kominn í. Hann varð fær um að skoða og trúa öðrum skýringum á meinlausum líkamlegum ópægindum sem hann, líkt og aðrir, fann og finnur enn fyrir með reglulegu millibili.

\section{Faraldsfræói heilsukvíða}

Öfugt við flestar aðrar kvíða- og líkömnunarraskanir virðist heilsukvíði vera jafn algengur hjá körlum og konum og getur hafist á hvaða aldri sem er, en algengast er að hann hefjist snemma á fullorðinsárum. ${ }^{3}$ Oft gerir heilsukvíði vart við sig pegar fólk er undir álagi, til dæmis í kjölfar veikinda eða andláts nákomins ættingja. Áætlað er að 2-6\% fólks veikist einhvern tíma á ævinni af heilsukvíða (lífsalgengi) ${ }^{4-6}$ en tölur eru nokkuð breytilegar par sem mismunandi viðmið hafa verið notuð. Hins vegar má ætla að mun fleiri, eða í kringum 10-20\% peirra sem eru heilbrigðir á hverjum tíma, hafi áhyggjur af að vera haldnir einhverjum sjúkdómi. ${ }^{7}$ Pá má nefna að 2550\% heimsókna á heilsugæslustöðvar tengjast umkvörtunum sem ekki finnast læknisfræðilegar skýringar á. ${ }^{8}$

Heilsukvíði virðist ekki háður menntunarstigi, kyni, kynpætti, félagslegum eða efnahagslegum aðstæðum. 6, 9-11 Er petta öfugt við hugbrigðaröskun sem einnig telst til líkömnunarraskana, en er algengari meðal kvenna, og fólks sem býr við lægra menntunarstig og í fátækari löndum. ${ }^{9}$

\section{Hugrænt skýringarlíkan heilsukvíoa}

Samkvæmt hugrænni kenningu Salkovskis og Warwick um heilsukvíða getur reynsla fólks af veikindum, hjá pví sjálfu eða öðrum, átt pátt í 
myndun neikvæðra og ósveigjanlegra hugmynda um veikindi, sjúkdómseinkenni, vinnubrögð lækna og svo framvegis. ${ }^{12}$ Andlát móður Gunnars, heilsukvíðna mannsins sem lýst er fyrr í greininni, stuðlaði til dæmis að peim hugmyndum Gunnars аð раð sama ætti fyrir honum að liggja og móður hans, að veikjast og deyja fyrir aldur fram. Hann próaði jafnframt með sér afar neikvæðar hugmyndir um veikindi, eins og að pau hlytu óhjákvæmilega að fela í sér miklar kvalir, bjargarleysi og örvæntingu. Gunnar leit einnig svo á að líkamleg einkenni mætti ávallt rekja til undirliggjandi sjúkdóms og að ekki væri á lækna treystandi til að greina sjúkdóma í tæka tíð.

Eins og sjá má á meðfylgjandi skýringarlíkani af heilsukvíða (sjá mynd 1) verður eitthvert pýðingarmikið atvik, eins og að greinast með frumubreytingar í leghálsi, til pess að pær hugmyndir sem fyrir eru um veikindi ýfast upp. Prálátrar tilhneigingar fer svo að gæta til að túlka líkamleg einkenni, eðlilegar líkamsbreytingar og heilsutengdar upplýsingar, til dæmis frá læknum eða niðurstöður læknisrannsókna, til marks um veikindi eða hættu á að veikjast alvarlega í náinni framtíð. Styrkur pessarar túlkunar ræðst af samspili eftirfarandi pátta: Líkum sem viðkomandi telur á að veikjast, hversu slæm hann álítur að veikindin yrðu, peim bjargráðum sem viðkomandi telur sig búa yfir til að fást við veikindin og peim utanaðkomandi páttum sem hann telur að gætu komið sér til aðstoðar. Samspil pessara pátta má sjá á mynd 2 .

Samkvæmt mynd 2 getur kvíðinn orðið mikill prátt fyrir að líkur á veikindum séu metnar litlar, par sem viðkomandi gæti álitið pað hroðalegt að veikjast með ákveðnum hætti og séð fyrir sér hægfara og kvalarfullt andlát, svo dæmi sé nefnt. Kvíðinn yrði enn meiri liti viðkomandi svo á hann yrði ófær um að takast á við veikindin og að pað væri ekkert sem læknavísindin gætu gert til að lina pjáningar hans. Sýnt hefur verið fram á að heilsukvíðnir meti hættuna meiri en aðrir á að veikjast af sjúkdómum ${ }^{13}$ og peir eru jafnframt líklegri en aðrir til að álíta sig veila og illfæra um að fást við streitu. ${ }^{14}$

\section{Skekkt úrvinnsla upplýsinga}

Samkvæmt hugrænni kenningu vinna einstaklingar með heilsukvíða úr heilsutengdum upplýsingum í samræmi við hugmyndir um veikindi og gætir ríkrar tilhneigingar til að gera ráð fyrir pví versta, horfa framhjá meinlausum skýringum á einkennum og taka upplýsingar úr samhengi. ${ }^{15}$ Gunnar varð til dæmis mjög upptekinn af ósértæku flekkjunum sem sáust við segulómskoðun og leiddi hjá sér pau

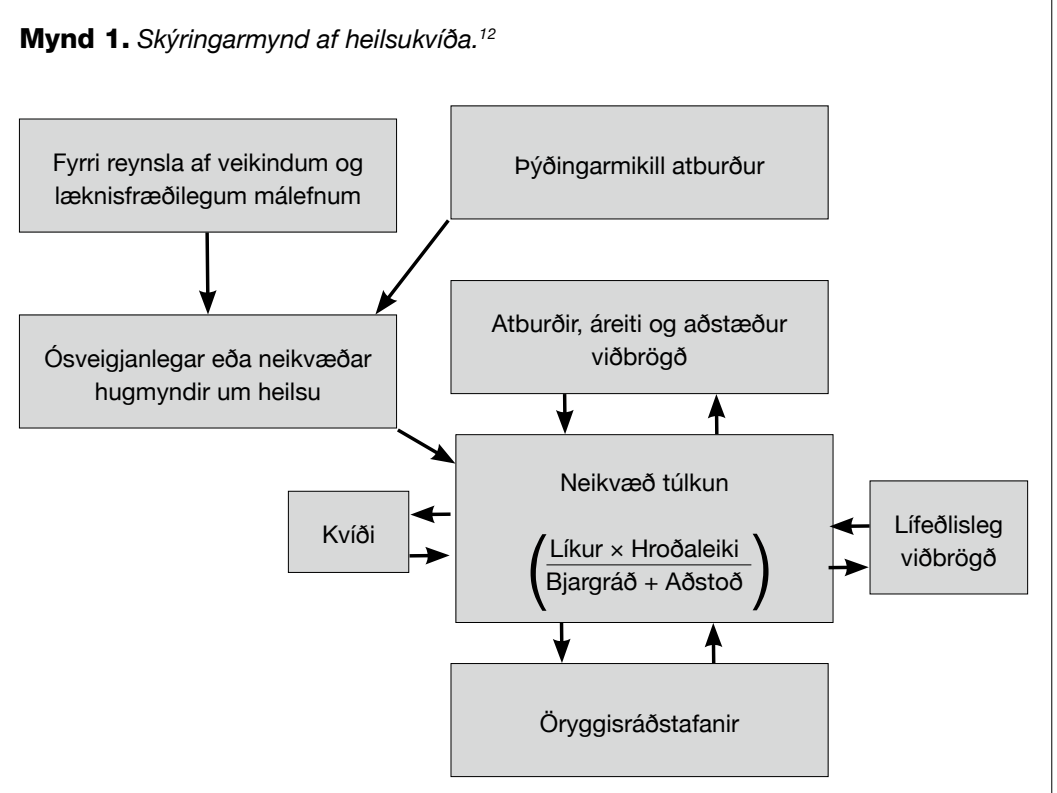

ummæli læknisins að engin teikn væru um MSsjúkdóminn.

Athygli fólks með heilsukvíða beinist sérstaklega að áreitum eða upplýsingum sem styðja pær hugmyndir sem fyrir eru, meðan upplýsingar sem benda til annars njóta minni athygli. ${ }^{12}$ Рað geta annars vegar verið utanaðkomandi upplýsingar sem fanga athygli heilsukvíðinna, eins og að heyra umfjöllun um tiltekinn sjúkdóm í fjölmiðlum. Rannsókn frá 1999 benti til pess að heilsukvíðnir ættu auðveldara með að muna heilsutengd orð en önnur orð og kom pessi skekkja ekki fram hjá samanburðarhópi. ${ }^{16}$ Pá benti önnur rannsókn til að heilsukvíðnir ættu auðveldara með að muna orð tengd sársauka. ${ }^{17}$

Athygli heilsukvíðinna beinist hins vegar að líkamlegum einkennum og líkamsbreytingum. Til dæmis gæti manneskja fylgst grannt með nýjum fæðingarblettum og óttast að um sortuæxli væri að ræða. ${ }^{18}$ Pekkt er að fólk finni meira fyrir eðlilegum líkamlegum ópægindum beini pað athyglinni að peim, ${ }^{19}$ og pví er hætt við að heilsukvíðnir magni upp hjá sér pau einkenni sem fyrir eru og telji pau stafa af undirliggjandi veikindum.

\section{Lífeðlisleg viðbrögð}

Hugsanir um alvarleg veikindi vekja gjarnan upp kvíða og streitu, jafnvel sorg og reiði. Pessum tilfinningum fylgja örvunartengd viðbrögð eins og aukinn hjartsláttur, vöðvaspenna,

\begin{tabular}{|c|c|c|c|}
\hline \multirow{2}{*}{ Kvíði = } & $\begin{array}{l}\text { Áætlaðar líkur } \\
\text { á veikindum }\end{array}$ & $x$ & $\begin{array}{l}\text { Áætlaður kostnaður, } \\
\text { hroðaleiki og byrði veikinda }\end{array}$ \\
\hline & $\begin{array}{l}\text { Áætluð bjargráð til } \\
\text { að fást við veikindi }\end{array}$ & + & $\begin{array}{l}\text { Áætlaðir ytri pættir } \\
\text { sem koma til aðstoðar }\end{array}$ \\
\hline
\end{tabular}


mæði og meltingartruflanir. Pá má nefna að örvunartengd einkenni frá meltingarfærum geta verið ógleði, magakrampar og niðurgangur. Langvarandi streitutengd vöðvaspenna getur lýst sér í vöðvakippum, andpyngslum og verkjum. Heilsukvíðnir eiga oft erfitt með að trúa pví að pessi einkenni séu meinlausir fylgifiskar kvíða. ${ }^{20}$

\section{Öryggisrádstafanir}

Öryggisráðstafanir eru varnarviðbrögð sem ætlað er að koma í veg fyrir eða draga úr líkum eða áhrifum skynjaðrar ógnar, en geta jafnframt átt pátt í að viðhalda óraunhæfum hugmyndum um ógnina. ${ }^{12}$ Til dæmis gæti manneskja sem óttast hjartaáfall tekið púlsinn á klukkutíma fresti og lagst niður í hvert sinn sem hún finnur fyrir auknum hjartslætti. Pessar öryggisráðstafanir aftra pví að hún komist að pví að ekkert alvarlegt gerist pótt hún sleppi pessum ráđstöfunum, hún sé hraust og poli eðlilegt álag.

\section{Ásókn í hughreystingu}

Augljósasta öryggisráðstöfunin meðal heilsukvíðinna er að sækja ítrekað í hughreystingu (reassurance) en hún getur falist í að spyrja maka eða fjölskyldumeðlimi út í einkenni eða lýsa einkennum ítrekað fyrir öðrum. Hún getur einnig einkennst af lestri um sjúkdóma eða endurteknum heimsóknum til lækna og beiðni um læknisrannsóknir. Hughreystingin felst pá í pví að utanaðkomandi aðili, oft læknir, komi pví ítrekað á framfæri að ekkert alvarlegt sé að, oft með vísun í niðurstöður læknisskoðunar og rannsókna. ${ }^{20}$

раð er freistandi að veita heilsukvíðnum hughreystingu en pað gerir peim lítið gagn og kann fremur að ýta undir heilsukvíðann pegar til langs tíma er litið. ${ }^{15}{ }^{20}$ Hughreystingin slær í fyrstu á kvíðann en kvíðinn tekur sig oftast upp á innan við sólarhring frá pví að hughreysting er veitt. ${ }^{13,}{ }^{21}$ Hætt er við að ásóknin í hughreystingu festist í sessi hjá peim heilsukvíðna, sem leið til að fást við kvíða, og er pað óheppilegt par sem um skammvinna lausn er að ræða sem krefst ítrekaðrar hughreystingar. Viðkomandi getur pannig orðið háður öðrum um hughreystingu sem ýtt getur undið bjargarleysi hans og ósjálfstæði. Pá stuðla pessi viðbrögð að pví að viðkomandi verji mun meiri tíma í umræður um heilsufar sitt, sem getur gert hann enn meðvitaðri um pau einkenni sem hann hræðist. ${ }^{20}$ Eins er hætt við að viðkomandi fái misvísandi upplýsingar frá öðrum, sem grafið getur undan trausti á aðra. ${ }^{15}$ Heilsukvíðnir prá að komast til botns í pví hvað hrjáir pá og vilja sumir frekar fá einhverja greiningu en að kljást við óvissuna. Ummæli Woodys Allen í hlutverki manns með heilsukvíða í myndinni Deconstructing Harry lýsa pessu vel: „Fallegustu orðin í enskri tungu eru ekki ég elska pig heldur pað er góðkynja."

\section{Líkamsskönnun}

Algengt er að einstaklingar með heilsukvíða skanni líkamann reglulega í leit að útlitsbreytingum eða líkamsósamhverfu. Algeng er preifing á ákveðnum stöðum eins og hálsi eða brjóstum til að athuga hvort eitthvað óvenjulegt finnist par. Endurtekin preifing getur framkallað eymsli sem eru svo túlkuð á versta veg. Jafnvel pótt engin eymsli hljótist af, viðheldur líkamsskönnunin aukinni meðvitund um líkamann, sem gerir pað að verkum að fólk tekur betur eftir ýmsum eðlilegum ópægindum og túlkar pau til marks um veikindi. ${ }^{15,20}$

Forðun

Forðun getur lýst sér með ýmsum hætti. Hinn heilsukvíðni getur til dæmis forðast „áhættusama hegðun“ eins og að reyna á sig líkamlega af hræðslu við að auka á einkennin og ofgera líkamanum sem álitinn er veikur fyrir. Pessi forðun kemur í veg fyrir að hann komist að pví að hann hafi í raun eðlilegt úthald og að ekkert alvarlegt gerist pótt hann reyni á sig. Hreyfingarleysið stuðlar svo smám saman að verra líkamsformi sem gerir pað að verkum að sá sem í hlut á finnur meira fyrir sleni, verkjum og spennu sem eru svo talin til marks um versnandi heilsufar, og vítahringur skapast. ${ }^{15}$

Heilsukvíðnir eiga pað einnig til að forðast aðstæður sem aukið geta á heilsukvíðann. Peir gætu til dæmis forðast að lesa minningargreinar eða hlýða á sjúkrasögur annarra. Sumir forðast læknisheimsóknir alfarið af ótta við að fá slæmar fregnir. Pessi viðbrögð hjálpa ekki, pví pau aftra pví að viðkomandi komist að pví að ekkert alvarlegt sé að. Viðbrögðin geta einnig gert pað að verkum að sá sem í hlut á komist of seint undir læknishendur, pá sjaldan eitthvað alvarlegt er að. Öll pessi forðunarviðbrögð koma í veg fyrir að sá heilsukvíðni komist að pví að hann ráði við aðstæðurnar. ${ }^{15,20}$

\section{Heilsukvíði og práhyggjuárátturöskun}

Margir telja að heilsukvíði ætti frekar að flokkast með kvíðaröskunum á borð við práhyggjuárátturöskun í stað líkömnunarraskana. Margt styður að svo sé. ${ }^{22-26}$ Báðar raskanirnar 
einkennast af miklum kvíðaeinkennum, prálátum hugsunum um ógnina og litlu óvissupoli. Í báđum röskununum sækja ópægilegar hugsanir að sjúklingunum og valda peim kvíða. Einstaklingar með práhyggjuárátturöskun og peir sem haldnir eru heilsukvíða leitast við að minnka kvíðann með öryggisráðstöfunum. Sá sem haldinn er práhyggju og áráttu kann til dæmis að ganga ítrekað úr skugga um að slökkt sé á eldavélinni en sá heilsukvíðni kann að leita ítrekað til læknis til að fullvissa sig um hann sé ekki alvarlega veikur. Slíkar ráđstafanir slá aðeins á kvíðann til skamms tíma og eiga í raun pátt í að viðhalda vandanum. ${ }^{15}$ Einnig hefur svipuð meðferð með serótónínendurupptökuhemlum borið árangur. ${ }^{25}$

\section{Meðhöndlun heilsukvíða}

Heilsukvíði pótti löngum illviðráðanlegur vandi en með tilkomu nýlegra rannsóknarniðurstaðna hafa pessar hugmyndir tekið að breytast. Teknar hafa verið saman helstu rannsóknir sem gerðar hafa verið á árangri mismunandi meðferðarforma við heilsukvíða. ${ }^{20}$ Hugræn atferlismeðferð og flúoxetín reyndust vera árangursríkustu meðferðarinngripin með áhrifastærðir (effect sizes) 2,05 og 1,92, sem samsvarar mjög góðum meðferðarárangri. ${ }^{27}$ Árangur hugrænnar atferlismeðferðar virðist haldast, í pað minnsta ári eftir að hún er veitt, en ekki er vitað hvort pað sama eigi við pegar töku lyfja er hætt. Pá mætti rannsaka betur hvort auka megi árangurinn með pví að sameina hugræna atferlismeðferð og lyfjameðferð. Einnig hefur komið í ljós að fræðsla ber góðan árangur við vægum heilsukvíða, en pá er veitt fræðsla í nokkur skipti um áhrif hugarfars, athygli, öryggisráðstafana og streitu á vandann..$^{28-31}$

Pegar einstaklingur með heilsukvíða leitar til læknis er sérlega mikilvægt að sýna hlýju og skilning. Í töflu II má finna frekari ráð um hvernig beri að nálgast fólk með heilsukvíða. Mælt er með að viðkomandi sé rannsakaður vandlega í upphafi par sem tilvist heilsukvíða útilokar ekki að líkamlegur sjúkdómur kunni að vera á ferðinni. Að pessum rannsóknum loknum er mælt með að sneitt sé hjá frekari rannsóknum par sem pær geta, eins og fram er komið, átt pátt í að viðhalda heilsukvíða. Í framhaldinu er mikilvægt að skoða með viðkomandi hvort meinlausar skýringar kunni að vera á einkennunum. Mikilvægt er að draga aldrei í efa líkamleg ópægindi viðkomandi, heldur aðeins pá hugmynd að einkennin séu til marks um alvarleg líkamleg veikindi. Gott er að útskýra að líkaminn sé sjaldnast einkennalaus og að líkamleg
Tafla II. Leiðir til að fást við heilsukvíða. ${ }^{20}$

pað sem ber að gera

- Sýna pjáningu viðkomandi samúo og skilning

- Sampykkja líkamlegar umkvartanir viðkomandi

- Grennslast fyrir um ástæður pess að viðkomandi telji sig veikan

- S Skoða með viðkomandi hvort meinlausar skýringar kunni að vera á líkamlegum ópægindum

- Fara yfir hugmyndir viðkomandi um vandann og reyna að leiðrétta misskilning

- Setja hugræna atferlismeðferð fram sem möguleika sem viðkomandi tapi engu á að̃ prófa, par geti hann öðlast betri skilning á heilsufarsáhyggjum sínum

- Benda á að pó að líkamleg ópægindi kunni að eiga sér vefrænar ástæður, geti hugræn atferlismeðferð hjálpað viðkomandi að fást við pau

- Ræða ókosti pess að flækjast milli lækna

Pað sem ber að forðast

- Senda viơkomandi í ónauðsynlegar rannsóknir

- Hughreysta viðkomandi með pví að segja honum ítrekað að ekkert sé að

- Gefa í skyn að umkvartanir séu ímyndun eða taugaveiklun

- Gefa viðkomandi lyf við líkamlegum kvillum

- Leiðast út í pras eða rökræður i stað pess að skoða málin í sameiningu

- Óreglulega og „einkennamiðaða“ fundi. Betra er að bjóða viðkomandi að koma reglulega í eftirlit

ópægindi tengist oft eðlilegum breytingum á líkamsstarfsemi sem meðal annars geta hlotist af breyttu svefnmynstri, mataræði, hreyfingu eða örvun tengdri kvíða eða öðrum tilfinningum. Kvíði einn og sér lýsi sér í fjölda líkamlegra einkenna, svo sem vöðvaspennu, slappleika, verkjum, svima, dofa, meltingartruflunum og auknum hjartslætti. $^{20}$

Ræða má hvort viðkomandi vilji aðstoð við að fást við heilsukvíðann og hverju pað myndi breyta fyrir hann ef hann næði tökum á kvíðanum. Nefna má hugræna atferlismeðferð sem kost sem viðkomandi tapi engu á að reyna, hann geti í pað minnsta lært að höndla einkennin betur og minnka heilsufarsáhyggjur og streitu. Pá megi jafnframt bæta líðanina með lyfjameðferð.

\section{Lyfjameðferð}

Lyfjameðferð, helst með serótónín-endurupptökuhemlum (SSRI), hefur reynst nokkuð vel við heilsukvíða prátt fyrir að fátt sé um tvíblindar rannsóknir. Mikilvægt er að meðhöndla aðrar samhliða geðraskanir, svo sem punglyndi, felmtursröskun og áráttu- og práhyggjuröskun. Hafi heilsukvíðinn komið í kjölfar annarrar geðröskunar nægir oft að meðhöndla frumvandann til að heilsukvíðinn minnki. Með serótónín-endurupptökuhemlum er oft hægt að slá tvær flugur í einu höggi pegar kemur að

Tafla III. Lyfjameðferð og skammtar.

\begin{tabular}{lcc} 
Lyf & Upphafsskammtur & Viðmiðunarskammtur \\
Flúoxetín & $5-10 \mathrm{mg} / \mathrm{dag}$ & $20-80 \mathrm{mg} / \mathrm{dag}$ \\
\hline Cítalopram & $10 \mathrm{mg} / \mathrm{dag}$ & $20-40 \mathrm{mg} / \mathrm{dag}$ \\
\hline Paroxetín & $10 \mathrm{mg} / \mathrm{dag}$ & $20-50 \mathrm{mg} / \mathrm{dag}$ \\
\hline Sertralín & $12,5-25 \mathrm{mg} / \mathrm{dag}$ & $50-200 \mathrm{mg} / \mathrm{dag}$ \\
\hline
\end{tabular}


lyfjameðferð heilsukvíðans og annarrar tengdrar röskunar. $^{32-34}$ Sérstaklega ber að nefna nýlega rannsókn sem sýndi fram á ápekkan árangur með paroxetín og hugrænni atferlismeðferð gegn heilsukvíða. ${ }^{35}$ Í töflu III má sjá yfirlit yfir helstu lyf og skammta sem notuð eru við heilsukvíða. Algengt er аð раð purfi að nota nokkuð háa skammta en eigi að síður er nauðsynlegt að byrja hægt par sem heilsukvíðnir eru sérstaklega viðkvæmir fyrir aukaverkunum, ekki síst í byrjun meðferðar. $33,36,37$

\section{Pakkir}

Höfundarnir pakka Aðalheiði D. Matthíasdóttur, Pétri Berg Matthíassyni og Helenu Jónsdóttur fyrir yfirlestur greinarinnar og góðar ábendingar.

\section{Heimildir}

1. American Psychiatric Association. Diagnostic and statistical manual of mental disorders (4th ed., text rev.).: APA Washington DC 2000.

2. Simon G. Psychiatric disorders and functional somatic symptoms as predictors of health care use. Psychiatr Med 1992; 10: 49-59.

3. Barsky AJ, Wyshak G, Latham KS, Klerman GL. Hypochondriacal patients, their physicians, and their medical care. J Gen Intern Med 1991; 6: 413-9.

4. Magariños M, Zafar U, Nissenson K, Blanco C. Epidemiology and treatment of hypochondriasis. CNS Drugs 2002; 16: 9-22

5. Barsky AJ. Clinical practice. The patient with hypochondriasis. N Engl J Med. 2001; 345: 1395-9.

6. Barsky AJ, Wyshak G, Klerman GL, Latham KS. The prevalence of hypochondriasis in medical outpatients. Soc Psychiatry Psychiatr Epidemiol 1990; 25: 89-94.

7. Kellner R. Hypochondriasis and somatization. JAMA 1987 258: 2718-22.

8. Barsky AJ. The validity of bodily symptoms in medical outpatients. In: Stone AA, Turkkan JS, Bachrach CA, Jobe JB, Kurtzman HS, Cain VS eds. The science of self-report Implications for research and practice. Mahwah, NJ Erlbaum, 2000: 339-61.

9. Kellner R. Somatization and hypochondriasis. Praeger, New York 1986.

10. Faravelli C, Salvatori S, Galassi F, Aiazzi L, Drei C, Cabras P. Epidemiology of somatoform disorders: a community survay in Florence. Soc Psychiatry Psychiatr Epidemiol 1997; 32: $24-9$.

11. Gureje O, Ustum TB, Simon GE. The syndrome of hypochondriasis: a cross-national study in primary care. Psychol Med 1997; 27: 1001-10.

12. Salkovskis PM, Warwick HMC Making sense of hypchondriasis: A cognitive model of health anxiety. In Asmundson GJG, Taylor S, Cox BJ (Eds.) Health anxiety: Clinical and research perspectives on hypochondriasis and related conditions. John Wiley \& Sons Ltd, New York 2001: 46-64.

13. Haenen MA, de Jong PJ, Schmidt AJ, Stevens S, Visser L. Hypochondriacs' estimation of negative outcomes: domainspecificity and responsiveness to reassuring and alarming information. Behav Res Ther 2000; 38: 819-33.

14. Rief W, Hiller W, Margraf J. Cognitive aspects of hypochondriasis and the somatization syndrome. J Abnorm Psychol 1998; 107: 587-95.

15. Wells A. Cognitive Therapy of Anxiety Disorders. John Wiley \& Sons, Chichester 1997.
16. Brown HD, Kosslyn SM, Delamater B, Fama J, Barsky AJ. Perceptual and memory biases for health-related information in hypochondriacal individuals. J Psychosom Res 1999; 47: 67-78.

17. Pauli P, Alpers GW. Memory bias in patients with hypochondriasis and somatoform pain disorder. J Psychosom Res 2002; 52: 45-53.

18. Miller SM, Brody DS, Summerton J. Styles of coping with threat: implications for health. J Pers Soc Psychol 1988; 54: $142-8$

19. Haenen MA, Schmidt AJ, Kroeze S, van den Hout MA. Hypochondriasis and symptom reporting - the effect of attention versus distraction. Psychother Psychosom 1996; 65: 43-8.

20. Taylor S, Asmundson GJG. Treating Health Anxiety: A Cognitive-Behavioral Approach. The Guilford Press, New York 2004.

21. Salkovskis PM, Warwick HM. Morbid preoccupations, health anxiety and reassurance: a cognitive-behavioural approach to hypochondriasis. Behav Res Ther 1986; 24: 597602

22. Abromowitz JS, Braddock AE. Hypochondriasis: Conceptualization, Treatment, and Relationship to Obsessive - Compulsive Disorder. Psychiatr Clin N Am 2006; 29: 50319.

23. Starcevic V. Relationship between Hypochondriasis and Obsessive-Compulsive Personality Disorder: Close Relatives Seperated by Nosological Schemes? Am J Psychother 1990; 154: 340-7.

24. Greeven A, van Balkom AJ, van Rood YR, van Oppen P, Spinhoven P. The boundary between hypochondriasis and obsessive-compulsive disorder: a cross-sectional study from the Netherlands. J Clin Psychiatry. 2006; 67: 1682-9.

25. Fallon BA, Oureshi AI, Laje G, Klein B. Hypochondriasis and its relationship to obsessive-compulsive disorder. Psychiatr Clin North Am. 2000; 23: 605-16.

26. Barsky AJ. Hypochondriasis and obsessive compulsive disorder. Psychiatr Clin North Am. 1992; 15: 791-801.

27. Cohen J. Statistical Power Analysis for the Behavioral Sciences (2. útg.). Lawrence Erlbaum Associates, Hillsdale 1988.

28. Bouman TK. A community-based psychoeducational group approach to hypochondriasis. Psychother Psychosom 2002; 71: 326-32.

29. Kroenke K, Swindle R. Cognitive-behavioral therapy for somatization and symptom syndromes: a critical review of controlled clinical trials. Psychother Psychosom 2000; 69: 205-15.

30. Clark DM, Salkovskis PM, Hackmann A, et al. Two psychological treatments for hypochondriasis: a randomised controlled trial. Br J Psychiatry 1998; 173: 218-25.

31. Stern R, Fernandez M. Group cognitive and behavioural treatment for hypochondriasis. BMJ 1991; 303: 1229-31.

32. Noyes R, Reich J, Clancy J, O'Gorman TW. Reduction in hypochondriasis with treatment of panic disorder. $\mathrm{Br} \mathrm{J}$ Psychiatry 1986; 149: 631-5.

33. Keeley R, Smith M, Miller J. Somatoform symptoms and treatment nonadherence in depressed family medicine outpatients. Arch Fam Med 2000; 9: 46-54.

34. Fava GA, Mangelli L. Hypochondriasis and anxiety disorders. In: Starcevic V, Lipsitt DR, eds. Hypochondriasis: modern perspectives on an ancient malady. Oxford University Press, Oxford, England 2001: 89-102.

35. Greeven A, van Balkom AJ, van der Leeden R, Merkelbach JW, van den Heuvel OA, Spinhoven P. Cognitive behavioural therapy versus paroxetine in the treatment of hypochondriasis: an 18-month naturalistic follow-up. J Behav Ther Exp Psychiatr 2009; 40: 487-96.

36. O'Malley PG, Jackson JL, Santoro J, Tomkins G, Balden E, Kroenke K. Antidepressant therapy for unexplained symptoms and symptom syndromes. J Fam Pract 1999; 48: 980-90.

37. Fallon BA, Schneier FR, Marshall R, et al. The pharmacotherapy of hypochondriasis. Psychopharmacol Bull 1996; 32: 607-11. 


\section{Health anxiety - increased knowledge and treatment options}

Patients with hypochondriasis are preoccupied with the fear or belief that they have a serious, undiagnosed disease. This concern derives from misinterpretations of benign physical sensations, and persists despite appropriate reassurance to the contrary. They have, on average, disproportionately high rates of visits to physicians, specialty consultations, laboratory tests, and surgical procedures, as well as high health care costs. Despite this extensive medical attention, they find their care unsatisfactory, which is understandable, as convincing alternative explanations to their ailments are repeatedly delayed. Physicians, in turn, may feel discouraged and frustrated in relation to these individuals where their best efforts to help often prove ineffective or are even rejected. Recent scientific studies have shown that cognitive behavioural therapy (CBT) and selective serotonin reuptake inhibitors (SSRI) are effective treatment options for health anxiety as demonstrated in clinical trials.

Davidsdottir SD, Sveinsson OA.

Health anxiety - increased knowledge and treatment options. Icel Med J 2020; 96: 755-61

Key words: hypochondriasis, somatoform disorders, cognitive behavioral treatment, selective serotonin reuptake inhibitors.

Correspondence: Ólafur Sveinsson, olafur.sveinsson@karolinska.se

Barst: 3. júní 2010, - sampykkt til birtingar: 14. október 2010 Hagsmunatengsl: Engin

\section{Seretide Diskus}

(Flútíkasón og salmeteról) ATC flokkur: R03AK06. R,0

Hver skammtur af Seretide Diskus gefur: 50 míkróg af salmeteróli (sem salmeterólxínafóat) og 100, 250 eđa 500 míkróg af flútíkasónprópíónati. Ábendingar: Astmi: Seretide Diskus er ætlað til samfelldrar međferđar gegn astma, par sem samsett meðferð (langverkandi berkjuvíkkandi lyfs og barkstera til innöndunar) á við: pegar ekki næst nægileg stjórn á sjúkdómnum með notkun barkstera til innöndunar og stuttverkandi berkjuvíkkandi (beta-2-örvandi) lyfja eđa pegar viðunandi stjórn á sjúkdómnum næst með notkun barkstera til innöndunar og langverkandi berkjuvíkkandi (beta-2-örvandi) Iyfja. Athugið: Seretide Diskus 50/100 míkróg styrkleikinn hæfir hvorki fullorđnum sjúklingum né börnum með slæman astma. Langvinn lungnateppa: Seretide Diskus er ætlað til meðferðar á einkennum hjá sjúklingum með langvinna lungnateppu með $\mathrm{FEV}_{1}<60 \%$ af áætluðu eðlilegu gildi (fyrir gjöf berkjuvíkkandi lyfs) sem hafa umtalsverð einkenni prátt fyrir reglulega meðferð með berkjuvíkkandi lyfjum og sögu um endurtekna versnun. Skammtar og lyfjagjöf Seretide Diskus er eingöngu ætlað til innöndunar. Gera parf sjúklingum ljóst að Seretide Diskus verður að nota daglega til að̃ ná hámarksárangri, jafnvel pótt einkenni séu ekki til staðar. Finna parf lægsta skammt sem nær að halda einkennum niðri. pegar hægt er að halda einkennum niðri með lægsta styrkleika samsettu međferðarinnar, tvisvar á dag, gæti næsta skref falist í að prófa eingöngu barkstera til innöndunar. Einnig væri hægt að finna hæfilegan skammt af Seretide Diskus, til notkunar einu sinni á dag, fyrir sjúklinga sem parfnast langvirks berkjuvíkkandi lyfs ef læknirinn telur bað nægja til bess að halda sjúkdómnum í skefjum. Ef lyfið er notað einu sinni á dag og sjúklingurinn hefur haft nætureinkenni gæti hann notað lyfið á kvöldin en ef sjúklingurinn hefur ađallega haft einkenni á daginn gæti hann notað lyfið á morgnana. Ef sjúklingur parf á skömmtum að halda sem liggja utan ráđlagđra skammtastærða, ætti að ávísa viðeigandi skömmtum af berkjuvíkkandi lyfi og/eđa barkstera. Rádlagđir skammtar: Astmi: Fullorðnir og unglingar 12 ára og eldri: Einn skammtur með 50 míkróg salmeteról og 100 míkróg flútíkasónprópiónat, tvisvar sinnum á dag eða einn skammtur með 50 míkróg salmeteról og 250 míkróg flútíkasónprópíónat, tvisvar sinnum á dag eđa einn skammtur með 50 míkróg salmeteról og 500 míkróg flútíkasónprópíónat, tvisvar sinnum á dag. Börn 4 ára og eldri: Einn skammtur međ 50 míkróg salmeteról og 100 míkróg flútíkasónprópiónat, tvisvar sinnum á dag. Hámarksskammtur af flútíkasónprópiónati í Seretide Diskus, sem skráđur er fyrir börn, er 100 míkróg tvisvar á dag. Upplýsingar varđandi notkun Seretide Diskus hjá börnum yngri en 4 ára, liggja ekki fyrir. Langvinn Iungnateppa: Fullorðnir: Einn skammtur með 50 míkróg salmeteról og 500 míkróg flútíkasónprópiónat, tvisvar sinnum á dag. Sérstakir sjúklingahópar: Ekki parf að breyta skömmtum hjá öldruðum eđa sjúklingum með skerta nýrnastarfsemi. pað liggja ekki fyrir upplýsingar um notkun Seretide Diskus hjá sjúklingum með skerta lifrarstarfsemi. Notkun Diskustækisins: Tækið er opnað og hlaðið með par til gerðri sveif. Munnstykkið er síðan sett í munninn og pað umlukið með vörunum. pá er hægt að anda skammtinum að sér og síðan er tækinu lokað. Frábendingar Seretide Diskus er ekki ætlað sjúklingum með ofnæmi fyrir virku efnunum eða hjálparefninu. Sérstök varnaðarorð og varúðarreglur við notkun Meðferð á astma ætti venjulega að fylgja áfangaáætlun og svörun sjúklings ætti að meta út frá klínískum einkennum og lungnaprófum. Seretide Diskus er ekki ætlað til meðhöndlunar á bráðum astmaeinkennum sem parfnast skjót- og stuttverkandi berkjuvíkkandi lyfja. Ráðleggja ætti sjúklingum að hafa lyf við bráđum astmaköstum ávallt við höndina. Önnur sérstök varnaðarorð og varúðarreglur við notkun (sjá nánar sérlyfjaskrártexta). Milliverkanir Forðast ber notkun bæði sérhæfðra og ósérhæfðra beta-blokka nema pörfin fyrir pá sé mjög brýn. Samtímis notkun annarra beta-adrenvirkra lyfja getur hugsanlega valdið aukinni verkun. Undir eðlilegum kringumstæđum łæst mjög lág péttni flútíkasónprópínats í plasma eftir innöndun lyfsins, vegna verulegra umbrota við fyrstu umferð um lifur og mikillar úthreinsunar fyrir tilstilli cýtókróms P450 3A4 í meltingarvegi og lifur. Pví er ólíklegt að klínískt mikilvægar milliverkanir við flútíkasónprópíónat komi fram. Meðganga og brjóstagjöf Ekki liggja fyrir nægjanlegar upplýsingar varđandi notkun á salmeteróli og flútíkasónprópínnati á međgöngu og við brjóstagjöf hjá konum, til pess að meta hugsanleg skaðleg áhrif. Notkun Seretide Diskus á međgöngu ætti einungis að̃ íhuga pegar væntanlegur ávinningur fyrir móđur er meiri en hugsanleg áhætta fyrir fóstur. Við međferð hjá punguðum konum ætti að nota lægsta skammt af flútíkasónprópiónati sem nægir til að halda astmaeinkennum í skefjum. Aukaverkanir bar sem Seretide Diskus inniheldur salmeteról og flútíkasónprópíónat má búast við aukaverkunum af sömu gerð og vægi og af hvoru lyfinu fyrir sig. Ekki eru nein tilfelli frekari aukaverkana pegar lyfin eru gefin samtímis. Mjög algengar ( $\geq 1 / 10)$, höfuđverkur, skjálfti. Algengar $(\geq 1 / 100$ og <1/10) hjartsláttarónot, erting í hálsi, hæsi/raddtruflanir, vöđvakrampar. Sjaldgæfar ( $\geq 1 / 1000$ og <1/100) Ofnæmisviðbrögð í húð, hraður hjartsláttur.Lyfjafræðilegar aukaverkanir beta-2-örvandi efna, svo sem skiálfti, hjartsláttarónot og höfuðverkur hafa komið fram, en hafa yfirleitt verið tímabundnar og minnkað við reglubundna meðferð. Vegna flútíkasónprópíonatpáttarins geta hæsi og sveppasýking í munni og hálsi komið fram hjá sumum sjúklingum. Hægt er að draga úr bæđi hæsi og tíðni sveppasýkinga með pví að skola munninn með vatni, eftir notkun lyfsins. Hugsanlegar almennar aukaverkanir eru m.a. Cushingssjúkdómur, einkenni sem líkjast Cushingssjúkdómi, bæling á nýrnahettustarfsemi, seinkun á vexti hjá börnum og unglingum, beinbynning, drer í auga og gláka. Örsjaldan hefur verið greint frá hækkun blóđsykurs. Eins og á við um önnur innöndunarlyf getur óvæntur berkjusamdráttur komið fyrir.

sjá nánar www.lyfjastofnun.is

\section{HANDHAFI MARKAĐSLEYFIS GlaxoSmithKline ehf. Pverholti 14,105 Reykjavík PAKKNINGAR OG VERĐ (Ágúst 2010)}

Seretide Diskus 50/100 míkróg/skammt innöndunarduft, 60 afmældir skammtar. Kr. 6.844 - Greiðslupáttaka B merkt Seretide Diskus 50/250 míkróg/skammt innöndunarduft, 60 afmældir skammtar. Kr. 11.104 - Greiðslupáttaka 0 merkt Seretide Diskus 50/500 míkróg/skammt innöndunarduft, 60 afmældir skammtar. Kr. 14.543 - Greiðslupáttaka 0 merkt Seretide innúđalyf 25/50 míkróg/skammt 120 skammtar. Kr. 6.597 - Greiðslubáttaka B merkt

Seretide innúđalyf 25/125 míkróg/skammt 120 skammtar. Kr. 9.222 - Greiðslupáttaka 0 merkt Seretide innúđalyf 25/250 míkróg/skammt 120 skammtar. Kr. 12.493 - Greiðslupáttaka 0 merkt 